\section{Approval hoped for soon}

\section{Washington}

A controversial survey on adult sexual habits in the United States, aimed principally at helping epidemiologists to predict how the AIDS virus will spread, is moving into the open again, having been stifled for months by opposition from within the Bush Administration. The survey, which includes questions on homosexual and bisexual practices, has already passed through a long bureacratic chain from its designers at the National Institute of Child Health and Human Development (NICHD) to the White House Office of Management and Budget (OMB) and back again. If the wrath of conservative congressmen such as William Dannemeyer (Republican, California) can be avoided, an expurgated version of the survey may soon come up for final approval.

Opposition to the survey has been channelled through OMB, which oversees all federally supported surveys. OMB director Richard Darman wanted a review of the survey to ensure that every question had a demonstrable purpose for AIDS researchers and that no unnecessary private questions were included.

He passed his request to Louis Sullivan, secretary of the Department of Health and Human Services. Sullivan passed the task to James Mason, his assistant secretary of health, who passed it to James Wyngaarden, director of the National Institutes of Health (NIH), who passed it to NICHD, which conducted an internal review as well as asking for the advice of its independent advisory panel. NICHD decided, without involving the scientists who had put together the original survey, to delete some of the questions. Out went inquiries about masturbation and sexual fantasies, which were deemed to have little relevance to the spread of AIDS. The panel unanimously endorsed the changes at its June meeting, since when the survey has worked its way back up the paper chain as far as Mason's desk, Wyngaarden having given it the imprimatur of NIH.

The survey is a pilot study of 2,300 people, costing about $\$ 2$ million, which is designed to help prepare a later full-scale survey. The National Opinion Research Center (NORC), a non-profit social sciences organization affiliated to the University of Chicago, has already been awarded the contract to conduct the pilot survey, which will consist of personal interviews, both in homes and in a research environment, and telephone interview.

Potential interviewees will be selected from lists of people who have already participated in public-health surveys on other matters. The selection will not be completely random, because the survey designers want to ensure that at-risk minorities, selected by age, marital status and ethnicity, for example, are adequately represented. Trained interviewers should be able to administer the survey in about an hour.

\title{
Old morality study finally surfaces
}

\section{Washington}

WHILE scientists struggle to set in motion an up-to-date survey of the sexual habits of people in the United States (see above), they can at least celebrate the belated publication of the results of a survey carried out almost 20 years ago. The data, which languished unseen because of a squabble over the manner of publication, reveal a population possessed of rather stern opinions: 60 per cent think that any kind of homosexual behaviour should be a crime, and 25 per cent would like to see laws prohibiting adultery.

"Sex and Morality in the US", published by the Wesleyan University Press, describes the beliefs and habits of a sample of 3,018 people who were questioned in late 1970 . The study was performed for the Kinsey Institute for Research in Sex, Gender, and Reproduction in an attempt to extend the Kinsey reports of the 1940 s and 1950s. Soon after the data were collected, some abbreviated accounts of the results emerged, but the details of the survey remained mired in a lengthy analysis which turned into a quarrel over the arrangement of authors' names and royalties. The study was published only in response to pressure from people who saw its potential value for AIDS research.

The study reveals something of a gap between what people think they ought to be doing and what they actually do. More than half the respondents declared that premarital sex is wrong, but almost 80 per cent had had intercourse with someone other than their spouse before they married, and 60 per cent expressed no regret about having done so. And although 60 per cent of Americans apparently think homosexuality should be outlawed, more than $\mathbf{5 0}$ per cent say they would remain friends with people they discovered to be homosexual.

The immediate relevance of the data to estimates of the spread of AIDS is questionable, because everyone in the survey was at least 21 years old in 1970 , long before the first cases of AIDS were recognized. The survey makes no attempt to determine the prevalence of practices that might be involved in the transmission of AIDS. For example, 17 per cent of men and 9 per cent of women said they had experienced some kind of homosexual activity, but it is not apparent what proportion of these respondents were simply confessing to teenage experimentation.
David Lindley
Among the questions that have caused problems are those on on the prevalence of past and present homosexuality in married men, and heterosexual anal intercourse. Researchers say they are essential because the poor quality of available data, much of which dates back to the Kinsey report of the 1940 s, prevents clear predictions of the future incidence of AIDS in the population at large. But opponents regard such questioning as intrusive when asked of people who are not obviously in any high-risk part of the population.

Dannemeyer, a dedicated conservative, has been the most vocal congressional critic of the survey. He believes such surveys are fundamentally unable to answer the questions they pose because people's willingness to respond depends on their proclivities. Dannemeyer favours instead a programme of confidential reporting of AIDS cases and tracking of sexual partners. He has no objections to asking specific questions about recent sexual contacts of people with AIDS; he and his colleagues oppose not so much the questions themselves as their being asked in what they regard as an indiscriminate manner.

Few congressmen have come out vocally in favour of the survey, although Representatives Bill Green (Republican, New York) and Henry Waxman (Democrat, California) have signed a letter of commendation to Sullivan. Supporters of the survey believe most politicians are on their side, but are nervous of saying so in an era when President Bush was elected on a wave of support for "family values".

$\mathrm{NIH}$ officials feel that once Sullivan gives his approval, the survey can go ahead. In a letter to Sullivan, Darman implied that his office has no legal power to prevent the survey, provided it passes proper scrutiny, and NIH officials are hoping that the pilot survey can go ahead without any public commotion.

But Dannemeyer is watching and, according to a spokesman, is ready to tell Darman the survey would be an embarrassment to the Bush administration. Failing that, he will try to have the process halted legislatively in the Senate, as the House of Representatives does not have that power. As the close-mouthed supporters of the survey are well aware, public attention is more important than legalistic nicety when such a charged issue is caught in the spotlight. David Lindley A plan to survey the sexual practices and attitudes of $20,000 \mathrm{UK}$ citizens to help predictions of the spread of the AIDS virus is under discussion following the successful completion of pilot studies. The survey is designed by Social Community Planning Research, the organization that would conduct it, together with researchers at Imperial College and the medical schools of St Mary's and Middlesex Hospitals, all in London. P.N. 